\title{
Fake News and Home Truths, Its Effects on the Contemporary Political Narratives: An Appraisal of India and Nigeria
}

\author{
Marysa Rachel Edwin \\ Ph.D. Arts and Media \\ University of Salford \\ Gilbert Laankwap Yalmi \\ Ph.D. Politics \\ University of Salford
}

\begin{abstract}
The on-going discussion on fake news is mostly focused on American and British societies in the political and social atmosphere of 'alternative facts' which is non-truth. However, the issues about the impact of fake news on journalism are not contained to British and American contexts only. This paper attempts to examine the alternative facts in Indian and Nigerian societies as well as the Journalism practices in this contemporary media-savvy phase. Unlike the issues projected in the western debate on the need to re-engage and empathize with the audience and the rise of a non-facts checking culture, the apprehensions appear to be slightly different in India and Nigeria. Findings in these two countries reveal that there is a higher rate of fake news pedalled around social media platforms. According to a study conducted in India and Nigeria by the BBC in 2018, it found out that the lack of faith in mainstream news made people spread unreliable information from varying sources. The study summarises how digital platforms like Facebook. Twitter and WhatsApp fuels people to share, comment and retweet information without fact-checking. Unfortunately, this has caused a lot of violence and lack of trust in politicians and their political narratives in both countries.
\end{abstract}

Keywords: fake news, home truths, Nigeria, India, politics

\section{Introduction}

World news these days does not only hold its relevance to traditional newspapers or news channels but has been spread widely through the growing dominance of social media platforms like Facebook, Twitter, WhatsApp, and LinkedIn. The verification of information or news shared via these platforms has been neglected hence an increase in false information has grown drastically via this medium of communication and interaction. Fake news became an on-trend topic of research and gained global popularity during the 2016 US presidential elections. The rise of fake news does not remain restrained only to western societies but is a growing phenomenon in countries like India and Nigeria. This term has found widespread research interest with regards to its influence and effects on Political campaigns via social media platforms (Mustafaraj \& Metaxas, 2017; Allcott \& Gentzkow, 2017; Groshek \& Koc-Michalska, 2017; Gu, Kropotov, \& Yarochkin, 2017; Jacobson, Myung, \& Johnson, 2016). This paper will be studying the effects and influence of Fake news on political campaigns via social media and the spread of political propaganda via social media in India and Nigeria. Social media networks such as Twitter and WhatsApp has been extensively used within both countries in exchanging information and thereby leading the quick broadcasting of public opinion (Schmidt A L, Zollo F, Del V M, 2017) for example in Nigeria President Muhammad Buhari was said to be cloned and that he was actually a man named Jubrin from Sudan, was one of the most widely circulated rumour during the 2019 election in Nigeria. In India, during the recent terrorists attacks news circulated via WhatsApp which claimed that the leader of the Congress party promised to pay the attackers family a large sum of money and free the terrorist if the state voted for Congress during the upcoming elections. This message was circulated widely via WhatsApp and was used to defame the Congress party as weak on militancy. Without proper verification and proper control, the fast circulation of false news can eventually reshape public opinion towards what is true or false information.

\section{Body of Work}

India is the largest democracy in the world with almost 1.37 billion people living in the country. The country since its very independence has focused on its spirit of nationalism within the masses always prioritizing national identity which was publicized via traditional media platforms. This increase in nationalism over the years has seen Indian citizens actively participate in the exchange and spread of fake news. With the internet easily available and accessible, the 
citizens of India have widely ignored mainstream news resources and have actively engaged in spreading unverified information with the intent of educating each other about the political domain within the country.

This constant engagement with unverified information via social media platforms like Twitter and WhatsApp has increased the threat of violence and political misconduct on a larger scale. Nigeria just like India has a large population with over 190 million people. Nigerian media has played a significant role in the political evolution of the country since independence, with the downsizing of military incursion into politics for close to 37 years which was characterized by the dictatorial rule, suspension of the constitution and clamping down on traditional media houses which affected freedom of expression. Thus giving rise to insinuations, and to what is referred to as today fake news. From 1999 with the dawn of the new democracy at the political sphere and with the rise of internet awareness and social media there is a wave of awareness amongst people to send out information which was hitherto were bottled up because of freedom of expression. This freedom of expression got expression in social media platforms like Facebook, WhatsApp, and Twitter. The vast amount of digital information shared via these social media platforms in 2018 has worsened the problem of fake news in both India and Nigeria. A BBC research conducted in India and Nigeria attempted to analyse and investigate the main source responsible for the spread of fake news, the study highlighted that people participated in actively commenting on Facebook post and images as well as forwarded WhatsApp messages from family and friends to others without verifying the information. The study also highlighted how people were confident with this ability and skill to spot fake news (Chakrabarti, Stengel, Solanki, Rooney \&Kweon 2018). However, the most fake news circulated within both countries has been constructed by political parties who hire people to create fake news mostly targeting their opponents in politics and religious minorities. Such fake news has always aimed at creating political animosity as well as evoke the feeling of prejudice among the masses. India and Nigeria in the past year have battled against the spread of fake news with political propaganda and have constantly struggled to curb extremist nationalism. Through the paper, we further intend to highlight the growing intolerance within the political realm in both India and Nigeria and how fake news is responsible for the rise of this political intolerance.

\section{Following are few case studies of Fake News in India and Nigeria}

During this year's election, the ruling political part in responding to the cloning of President Buhari also came up with fake news, that the opposition political party flag bearer Atiku Abubakar was not a Nigerian but a Cameroonian. This is Fake news because Atiku Abubakar was at one time the second-highest deputy controller of the Nigerian custom services and former Vice president between 1999 to 2011 (Adegoke et al., 2019).

In India, the recent airstrikes undertaken in Pakistan to curb militancy were backed by doctored photos which were circulated via WhatsApp to prove the success of the attacks. Its success was also confirmed by the ruling party who confirmed that many militants were killed during these attacks. However, this news was denied by Pakistan who claimed that there were no casualties during the attack. Most of the pictures shared through WhatsApp were pictures of past events of suicide bombings in Pakistan during 2014. This spread of fake news questioned the credibility of the governing political party (Ponniah, 2019).

\section{Appraisals of Fake News:}

Apart from reflecting India's robust democracy, these elections are drawing attention because of the role of social media in shaping India's political discourse, and specifically in transforming the face of the general elections held in 2014. Since then, social media platforms have emerged as an important political tool employed by every political party to communicate with their constituencies. With 45 million new young voters added to the electoral roll since 2014, the role of the new media and the proliferation of social media means that the public space has been enlarged like never before. This scenario is also prevalent in Africa's largest democracy Nigeria. In Nigeria, their president Muhammadu Buhari used his visit to the U.N summit to deny rumours that had were spread across social media about him dying an being replaced by a clone from Sudan named Jubrin. This fake news that spiralled across many social media platforms and news outlets were backed up by tampered photos that were circulated among people through Nigeria's booming platform WhatsApp. This is one example of fake news that spirals around Nigeria during elections. Many social media platforms have been responsible for the spread of fake news. However, WhatsApp has predominately been more active in the spread of fake news. In India, WhatsApp governs an approximately 200 million user base and its security and privacy ethics have continuously been a topic of debate especially when used by political parties for influencing people with political propaganda, spreading fake news and uploading tampered photographs. On the other hand, the growing trend of using extracts from speeches for bias political gain is gaining momentum. Videos streamed by YouTube which is the biggest streaming video app in India has also spread fake news amongst citizens of India. In India regional platforms like Share chat and TikTok ( a Beijing app) have also stirred political propaganda by spreading un-true and tampered news. Fake news affects those who use the internet and social media platforms for the first time and most of 
them are semi-illiterate to online ethics and knowledge. According to a report by the Hindustan Times, an Indian newspaper, the content feeds in Hindi and Kannada are equally littered with misinformation.

In Nigeria, Fake news has caused problems with people being killed due to political hostility which promotes the degrading and shaming of political members. CrossCheck Nigeria which is a platform that cross-checks if each news, photo or video is authentic recently discredited allegations that Nigeria's first lady wanted fellow Nigeria's to vote against her husband the President. Also, allegations that President Trump was supporting the opposition candidate Atiku Abubakar which was also discredited. Nigeria's election has always caused political turmoil, but its current election is mostly promoted through a WhatsApp wave which allows stories, messages, videos to be shared among people. With its simple user interface, minimal entry requirements and affordability, WhatsApp are many Nigerians' and Indian's primary source of modern age communication. The points mentioned below highlights how WhatsApp is instrumentally fuelling the spread of fake news in both countries.

- WhatsApp has made it convenient for people to be a part of many groups on this platform. A group can a have a maximum of 256 members and one person can be a member of different groups, thus making it easy to spread information, thought, concepts and ideologies to a large number of friends, colleagues, and acquaintances. Hence this explains how fake news can be spread to a large community of people in different groups.

- Political parties have misused WhatsApp for the use of promoting political agenda by hiring youths to spread their political campaign and fake information to defame the opposition party or to gain popularity amongst its voters. Since WhatsApp fails to reveal the source from where the information was first sent, the youth hired by these political parties have built several hundred networks for their parties to promote political propaganda.

- Most information shared on WhatsApp has been judged as credible, as most of the messages come from family, friends 'colleagues or acquaintances whom we trust. Even illiterate people believe the information as it is mostly circulated by individuals whom they trust.

\section{Rise of Violence caused by Fake news}

The rise of fake news has stirred the political atmosphere with misinformation spread from various platforms to people who are indulging and believing in every information they come across. However, the impact of fake news through social media has not only caused political turmoil but has caused an increase in violence across the states in India and Nigeria. Given the two nations largely democratic population made up of different religious groups and ethnicities, are always a cause of concern as the spread of fake news during the election season gives rise to religious and ethnic violence. During this year's election the northern state of Nigeria, Plateau was subject to violence due to fake news that was circulated via Facebook (Adegoke, 2019). This area in Nigeria is already subject to ethnic violence, a post in Facebook circulated on June 23, 2018, showing pictures of a man's skull open and a baby with machete wounds across its head and jaw was made viral around Facebook and was watched about 11,000 times. The news which was circulated by the user was claimed to project the growing violence in the Gashish district of Plateau State, Nigeria(Adegoke, 2019). According to the claims a tribe called the Fulani Muslims were killing Christians of Berom ethnic minority. This news engulfed hatred among both tribes costing the life of Many Fulani Muslims in the region. In India, the fight against fake news spread via WhatsApp has been responsible for violence and deaths caused by the country (Adegoke, 2019). Since 2014 social media has caused communal violence two such cases to mention is the "Kathua Rape Case" in 2018 which was the rape of an 8-year-old girl called Asifa Bano in the state of Kathua in the region of Jammu and Kashmir(Teitelman, 2019). The second was the Dadri Mob lynching in 2015 which saw a 52-year-old Muslim man Muhammad Akhlaq being killed and attacked by a mob of village people who accused him of slaughtering a cow(Teitelman, 2019). Although the attacks have no direct political connection and neither was initially caused by social media, however, the aftermath of these attacks have used the platform of social media to insinuate ill feelings and violence among many protestors. In both the incidents mentioned above, much of the violent aftermath was caused by the use of viral images, videos and message to ignite communal violence.

\section{Conclusion}

Form the above narratives in both countries of India and Nigeria, It shows that the lack of control or checks on the use of social media platforms in transmitting negativity and has caused high rate of cynicism and apathy amongst the people especially the thriving very energetic youth groups, which sometimes are not properly educated or have the maturity to decipher or sieve information and give it a rational thought before disseminating such information's. The social media platforms in the 21st century is supposed to be a platform where people meet and engage in communicative interactions of all spheres of influences which could range from different topics of context. Unfortunately, from our analysis, we have highlighted that in both India and Nigeria the rise of fake news via social 
media platforms has caused the loss of lives, property, and ethics. It is important for practitioners of these platforms to come up with effective systems to combat and check misinformation's that are circulated for online consumption. This paper will help open future research into the related effects of fake news and its consequences.

\section{References}

Adegoke, Y. (2019). Nigerian police say "fake news" on Facebook is killing people - BBC News. [online] BBC News. Available at: https://www.bbc.co.uk/news/resources/idt-sh/nigeria_fake_news [Accessed 17 May 2019].

Adegoke, Y., Northcott, C., Leroy, A. and Jari, A. (2019). Nigerian police say "fake news" on Facebook is killing people - BBC News. [online] BBC News. Available at: https://www.bbc.co.uk/news/resources/idtsh/nigeria_fake_news [Accessed 16 May 2019].

Allcott, H., \& Gentzkow, M. (2017). Social Media and Fake News in the 2016 Election. Journal of Economic Perspectives, 31(2), 211-236 Communication \& Society, 19(7), 875-891.

Chakrabarti Santana, Stengel Lucile \& Solanki Sapna. (2018). DUTY, IDENTITY, CREDIBILITY Fake news and the ordinary citizen in India, BBC report, cited (12/04/19) https://downloads.bbc.co.uk/mediacentre/duty-identitycredibility.pdf

Chakrabarti Santana, Rooney Claire \& Kweon Minnie . (2018). DUTY, IDENTITY, CREDIBILITY Fake news and the ordinary citizen in Kenya and Nigeria- A comparative study BBC report, cited (12/04/19) http://downloads.bbc.co.uk/mediacentre/bbc-fake-news-research-paper-nigeria-kenya.pdf

Groshek, J., \& Koc-Michalska, K. (2017). Helping populism win? Social media use, filter bubbles, and support for populist presidential candidates in the 2016 US election campaign. Information Communication and Society, 20(9), 1389-1407.

Gu, L., Kropotov, V., \& Yarochkin, F. (2017). The Fake News Machine: How Propagandists Abuse the Internet and Manipulate the Public. TrendLabs Research Paper. Retrieved from https://documents.trendmicro.com/assets/white_papers/wp-fake-news-machine-how- propagandists-abuse-theinternet.pdf

Jacobson, S., Myung, E., \& Johnson, S. L. (2016). Open media or echo chamber: the use of links in audience discussions on the Facebook Pages of partisan news organizations. Information,

Mustafaraj, E., \& Metaxas, P. T. (2017). The fake news spreading plague: Was it preventable? In WebSci 2017 Proceedings of the 2017 ACM Web Science Conference (pp. 235-239).

Ponniah, K. (2019). WhatsApp: The 'black hole' of fake news in India's election. [online] BBC News. Available at: https://www.bbc.co.uk/news/world-asia-india-47797151 [Accessed 16 May 2019].

Teitelman, C. (2019). Communal Violence, Social Media, and Elections in India. [online] JIA SIPA. Available at: https://jia.sipa.columbia.edu/online-articles/communal-violence-social-media-and-elections-india [Accessed 17 May 2019].

Schmidt A L, Zollo F, Del V M, et al. Anatomy of news consumption on Facebook[J]. Proceedings of the National Academy of Sciences of the United States of America, 2017, 114(12):3035. 